\title{
Evaluating the Connection between Thermal Comfort and Productivity in Buildings: A Systematic Literature Review
}

\author{
Ana Maria Bueno (D), Antonio Augusto de Paula Xavier and Evandro Eduardo Broday *(D) \\ Ergonomics Laboratory_Postgraduate Program in Production Engineering (PPGEP), Federal University of \\ Technology—Paraná, Rua Doutor Washington Subtil Chueire, 330, Jardim Carvalho, \\ Ponta Grossa 84017-220, Paraná, Brazil; anam@utfpr.edu.br (A.M.B.); augustox@utfpr.edu.br (A.A.d.P.X.) \\ * Correspondence: broday@utfpr.edu.br
}

Citation: Bueno, A.M.; de Paula Xavier, A.A.; Broday, E.E. Evaluating the Connection between Thermal Comfort and Productivity in Buildings: A Systematic Literature

Review. Buildings 2021, 11, 244

https: / / doi.org/10.3390/

buildings11060244

Received: 30 April 2021

Accepted: 2 June 2021

Published: 7 June 2021

Publisher's Note: MDPI stays neutral with regard to jurisdictional claims in published maps and institutional affiliations.

Copyright: (c) 2021 by the authors. Licensee MDPI, Basel, Switzerland This article is an open access article distributed under the terms and conditions of the Creative Commons Attribution (CC BY) license (https:// creativecommons.org/licenses/by/ $4.0 /)$

\begin{abstract}
The thermal environment is one of the main factors that influence thermal comfort and consequently, the productivity of occupants inside buildings. Throughout the years, research has described the connection between thermal comfort and productivity. Mathematical models have been established in the attempt to predict changes in productivity according to thermal variations in the environment. Some of these models have failed for a number of reasons, including the understanding of the effect that several environment variables have had on performance. From this context, a systematic literature review was carried out with the aim of verifying the connection between thermal comfort and productivity and the combinations of different thermal and personal factors that can have an effect on productivity. A hundred and twenty-eight articles were found which show a connection between productivity and some thermal comfort variables. By means of specific inclusion and exclusion criteria, 60 articles were selected for a final analysis. The main conclusions found in this study were: (i) the vast majority of research uses subjective measures and/or a combination of methods to evaluate productivity; (ii) performance/productivity can be attained within an ampler temperature range; (iii) few studies present ways of calculating productivity.
\end{abstract}

Keywords: thermal comfort; productivity; predicted mean vote; predicted percentage of dissatisfied; buildings

\section{Introduction}

Indoor Environmental Quality (IEQ) includes factors such as acoustic comfort, visual comfort, indoor air quality, and thermal comfort. Studying these factors is extremely relevant, since people spend a large part of their day inside buildings [1]. In addition to providing comfort to its occupants, buildings must also have low energy consumption and concern with sustainability [2]. At least a third of the day is connected to work-related activities, so one can see that productivity is related to IEQ parameters [3,4]. Studies show evidence that poor IEQ may cause diseases, negatively affecting the worker's well-being, and reduce its productivity [5-10].

Over the years, studies have shown that when people are not satisfied with the indoor environment, effects on the comfort, health, and productivity of these occupants are noticed [11,12], since the lack of environmental comfort causes occupants to spend energy and attention trying to make up for this lack of comfort, instead of focusing on their main activity [13]. Thus, improving IEQ can increase productivity between $0.5 \%$ and $5 \%[14,15]$.

Mui et al. (2019) [16] claim that when high standards of thermal comfort are obtained, excellent IEQ conditions are verified. According to Fanger (1970) [17], the main objective in creating thermal comfort in an environment is to satisfy the wish of its occupants to feel thermally comfortable. Thermal comfort represents the state of mind expressing thermal satisfaction with the environment and this is subjectively evaluated [18]. When people feel thermally comfortable, they are able to be more productive. This definition emphasises the 
fact that comfort is a process which involves many cognitive elements that are influenced by physical, physiological, and other processes [18].

Air temperature is a commonly used indicator in thermal environment in IEQ and in performance research [7]. Field and laboratory studies held in the last decades have reported the connection between air temperature and the performance of its occupants [3]. The physical effects obtained in the thermal environment may vary and may affect the performance of workers, affecting their productivity. Kosonen and Tan (2004) [19] claimed that the connection between thermal environment and productivity has attracted the attention of researchers.

Studies have analyzed the close link between performance and thermal comfort of the occupants in the workplace with considerable results on the levels of productivity [20-25]. In addition, the lack of thermal comfort results in "environmental stress", producing a negative tendency $[25,26]$.

As the definition of productivity can vary depending on the context, it is important to differentiate the related concepts: activity, performance, and productivity. Parsons (2014) [27] suggests that activity covers overall activities and can include psychological and physiological components, but is not directed towards any specific operational objective. Performance, on the other hand, is the result of an activity aimed at a goal where the performers deliberately regulate their behaviour to attain that aim. According to Bailey (1982) [28], human performance is the conclusion of work done by a human operator or team. The work may be at different levels, from the simple to the complex, manual, or automatized. In general, human performance can be measured by speed and time, precision and error, work force or capacity on demand and preference. Measuring these categories must be adapted to the kind of work to be measured and its environment [29].

Productivity, in turn, does not present a common definition. It is related to individuals' performance with respect to their goals and can best be characterized and quantified in offices or commercial buildings [30]. Oseland (1999) [31] states that productivity can be expressed in terms of efficiency, that is, ratio for entry towards exit. According to Ilgen and Schneider (1991) [32], the occupant's productivity can be measured in three ways: physiologically, objectively, or subjectively. In operational and organizational terms, productivity can be described as the ratio between the company's turnover and employee cost [33]. In the case of an office environment, performance/productivity can be measured using different criteria such as individual performance, team performance, and organizational performance $[31,34,35]$. Different dimensions can affect productivity such as social, environmental, organizational, and personal factors.

However, there is a limit to the studies which determine mathematical models and relations between productivity and physical factors of the indoor environment, such as thermal comfort, visual comfort, acoustic comfort and air quality, among others. For several years, the aspects of IEQ have been analyzed separately [36] and there are other factors that should be considered, such as multisensory interactions [2].

Several studies evaluated the effect of learning and the results show that the learning ratio decreases with the rise in temperature [7,37-41]. The change in performance in office work was also tested. The results showed that indoor air has an important effect on office worker productivity [14,42,43]. According to Tarantini et al. (2017) [44], the results indicate that comfortable indoor thermal conditions can have beneficial impact on workers' wellbeing and productivity such as higher operational rates, less production losses, fewer medical leaves, and cost reduction related to health.

Therefore, the aim of this study is to verify the state of the art of productivity with regards to thermal comfort, aiming to answer three research questions (RQs) proposed in this paper, as well as to verify the main characteristics of these studies, highlighting the ways of calculating productivity and environmental factors as well as ascertaining how productivity is related to thermal comfort variables. The organization of this paper is as follows: Section 2 describes the search strategy and framework used to perform this review. Section 3 analyses the main results provided by the selected articles. In Section 4, a detailed 
analysis from data is performed. In Section 5, future trends and gap researches are pointed out. In Section 6, the conclusions and limitations of this paper are summarized.

\section{Materials and Methods}

The methodology used in this study was based on two stages: planning the research where the aims are analyzed and the research questions (RQs) are made; a method for conducting the research in order to select and form the basis for the articles.

\subsection{Analysis of the Objectives and Defining the Research Questions (RQs)}

The main aim of this study is to check the state of art with regards to the existing connection between productivity and thermal comfort. To reach this goal, the three RQs are here presented:

(a) Currently, people spend up to $87 \%$ of their time in indoor environments, be it in residential or commercial buildings, and another $6 \%$ in their vehicles, and thus are continually being exposed to the indoor environment [45]. According to Wong et al. (2007) [46], the acceptance of an environment by its occupants depends on environmental parameters, namely thermal comfort, indoor air quality (IAQ), sound, and visual comfort, which are identified to determine indoor environmental quality.

RQ1. Which indoor environmental quality parameters are taken into account in order to evaluate productivity?

(b) Different levels of activity require specific environmental conditions for people, in order to attain thermal comfort. Throughout all these years of research, it is generally agreed upon that there must be an ideal temperature or, more precisely, an ideal temperature range for performance. Thermal comfort strongly influences the occupants' productivity. The occupants who report complaints of thermal discomfort reported low productivity [21,47,48]. Seppänen and Fisk (2006) [37] studied the connection between temperature and productivity and showed that maximum performance was observed at $21.6^{\circ} \mathrm{C}$. On the other hand, the theory of adaptative comfort by De Dear and Brager (1998) [49] suggests that ideal productivity can be reached on a wider scale of indoor temperatures. Based on this premise, RQ2 is devised:

RQ2. Is there a thermal condition which is considered ideal for increasing productivity?

(c) Productivity is related to individuals' performance with regards to their objectives. So far, there is no standard for measuring productivity and it is not easy to measure the thermal effect on human performance at the workplace because there are many variables related to specific tasks in specific contexts which cannot be adequately recorded [50]. RQ3 is devised based on this reference:

RQ3. Taking several studies into account on the connection between thermal comfort and productivity, how can productivity be calculated?

\subsection{Systematic Literature Review: Selecting and Forming Articles Database}

\subsubsection{Search Strategy}

To search for articles, key words were combined two by two on the basis of selected data. The combined words were "Thermal Comfort" AND "Predicted Mean Vote", "Thermal Comfort" AND "Predicted Percentage of Dissatisfied", "Thermal Comfort" AND "Productivity", "Predicted Mean Vote" AND "Predicted Percentage of Dissatisfied", "Predicted Mean Vote" AND "Productivity" and "Predicted Percentage of Dissatisfied" AND "Productivity". When revising, the PRISMA method was used-Preferred Reporting Items for Systematic Reviews and Meta-Analyses [51]. Throughout the years, other researches were done using the PRISMA method [52-54], a method which combines key words and does research on scientific information databases. The method has four stages for reducing 
the number of articles which will be selected: identification (step 1), selection (step 2), eligibility (step 3), and inclusion (step 4) for analysis.

As a strategy for identifying articles (step 1), the search area on the database was defined, and this included electronic database: Web of Science, Scopus, and Science Direct. Preliminary research was done on research-targeted predetermined databases observing the range of key words on the titles of studies, in abstracts and key words. Defining these bases was done because they were considered relevant to the study area under discussion and because the main magazines which publish information on thermal comfort are indexed on these bases. The research was carried out on all the years, aiming at a greater range of studies and checking out for the topic in all the time periods to ensure that all classical articles on the topic were taken into account. Articles on conferences, book chapters, and posters were excluded. The final research was done on December 2020. After the identification phase, the selection phase (step 2) began where inclusion and exclusion criteria were applied.

\subsubsection{Inclusion and Exclusion Criteria}

Initially, the articles were analyzed to identify significant studies related to the proposed aim. The first selection phase was done on study titles. Any title that had the potential to be included was selected for the abstract; subsequently the full text was evaluated to see if the title and the abstract of the study were inconclusive of inclusion or exclusion from the current systematic revision. Next, to determine if a study must be included, the criteria for inclusion and exclusion were applied according to Table 1.

Table 1. Inclusion and exclusion criteria.

\begin{tabular}{ll}
\hline \multicolumn{1}{c}{ Inclusion Criteria } & \multicolumn{1}{c}{ Exclusion Criteria } \\
\hline a. Studies published in English & a. Studies published in other languages \\
\hline b. Relevant to terms in the research & b. Articles with no link to research terms \\
\hline $\begin{array}{l}\text { c. Relevant studies published until 2020 } \\
\begin{array}{l}\text { d. Published studies with the potential to answer at } \\
\text { least one research question }\end{array}\end{array}$ & $\begin{array}{l}\text { c. Studies with no bibliographical information such } \\
\text { editions were excluded. }\end{array}$ \\
\hline
\end{tabular}

The next step consisted of a preliminary analysis of the selected articles with full and accessible texts. Eligibility (step 3) consisted of reading the abstracts to check if the selected articles could answer at least one of the RQs, this being a second refining. After the refining, the portfolio was obtained which contained the articles to be analyzed (step 4).

\section{Results}

\subsection{General View of the Selected Studies}

The logical combinations used for the research in the databases as well as the number of studies which were found are presented in Table 2.

Table 2. Research in Databases.

\begin{tabular}{|c|c|c|c|}
\hline Title, Abstract, Keywords & Science Direct & Scopus & Web of Science \\
\hline "Thermal Comfort" AND “Predicted Mean Vote" & 351 & 683 & 546 \\
\hline "Thermal Comfort" AND "Predicted Percentage of Dissatisfied" & 67 & 137 & 115 \\
\hline "Thermal Comfort" AND "Productivity" & 138 & 316 & 400 \\
\hline "Predicted Mean Vote" AND "Predicted Percentage of Dissatisfied" & 47 & 102 & 82 \\
\hline "Predicted Mean Vote" AND “Productivity" & 11 & 34 & 32 \\
\hline "Predicted Percentage of Dissatisfied Users" AND “Productivity" & 2 & 6 & 5 \\
\hline Total & 616 & 1232 & 1102 \\
\hline
\end{tabular}


The results of the search strategy through combinations of key words in the selected databases can be seen in Figure 1, applying the PRISMA method.

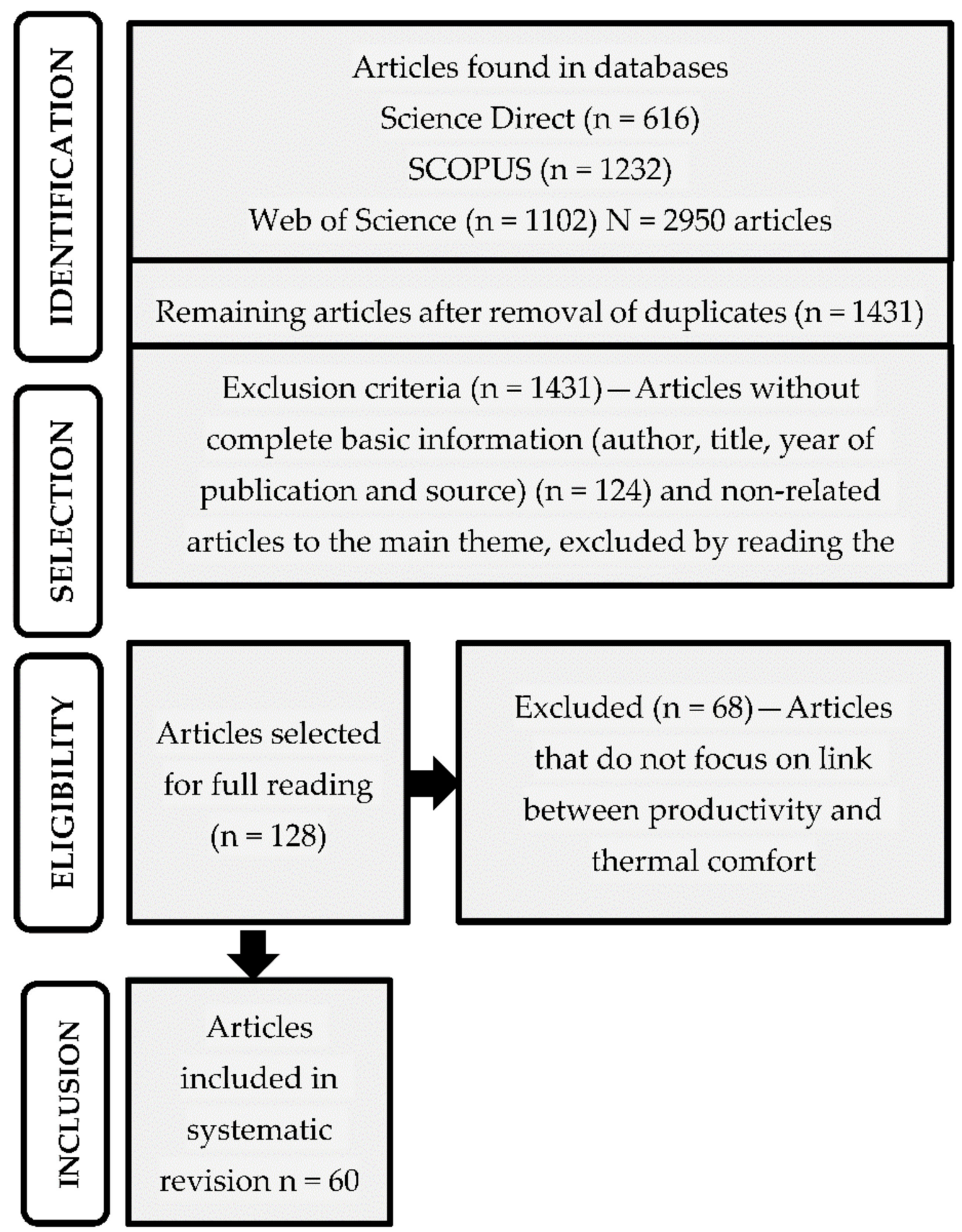

Figure 1. Results after applying the PRISMA method.

A total of 2950 articles were included in the revision of all databases. Following this, duplicated studies were removed, that is, articles which were in one or more databases and articles with incomplete information. Several articles were removed and after preliminary screening, 1431 articles were left. After reading the studies with titles, abstracts, or keywords which were not related to the theme being researched, 128 articles were left to be fully read and classified using the proposed methodology. Finally, the question or evaluation criteria were applied to these 128 studies. At the end of the exercise, 60 studies were selected and considered apt to provide answers to the research questions. After analysing the key words in the articles, Figure 2 has the number of studies published in journals, 
represented by vertical bars, followed by impact factor (IF), here represented by lines. The impact factor used to make Figure 2 was obtained from the site Incites Journal Citation Reports Clarivate Analytics. Besides this, the number of published articles each year is shown together with the caption, in different colors according to the year of publication.

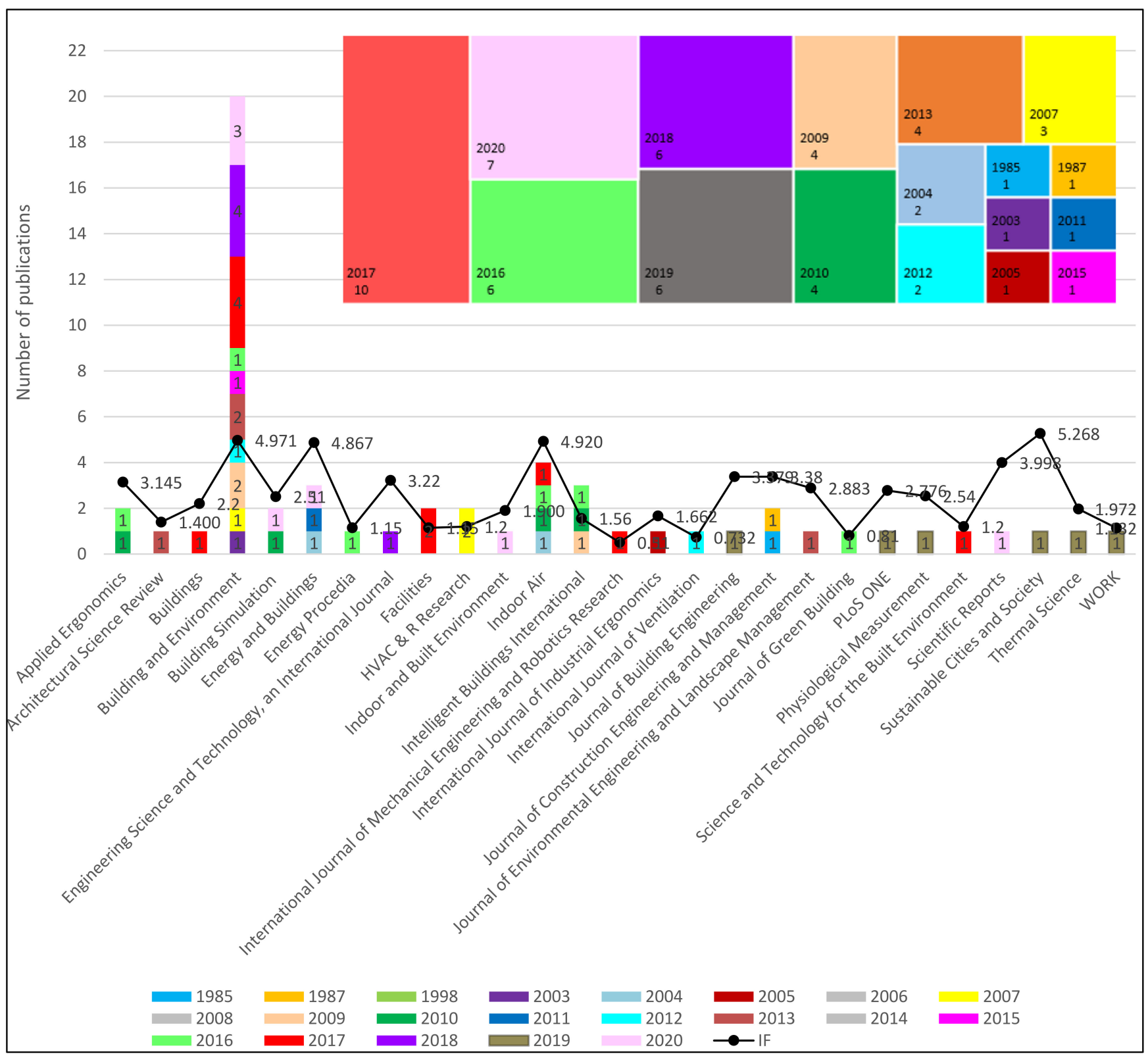

Figure 2. Co-occurrence map.

This research did not apply any time limit for the search of articles; the time period for the selected articles was 1985-2020. It was noted that there was a large number of publications in the last five years (2016-2020), corresponding to 35 of the 60 analyzed articles. In the research, the following journals are highlighted: Building and Environment (20), Indoor Air (4), Intelligent Buildings International (3), Energy and Buildings (3).

\subsection{Review Papers}

Of the 60 selected papers, 7 are review papers. Table 3 presents the main characteristics of these studies and also the number of citations, according to Google Scholar: 
Table 3. Review papers.

\begin{tabular}{|c|c|c|c|c|c|}
\hline Ref. & Year & Title & Journal/Impact Factor & $\begin{array}{l}\text { Number of } \\
\text { Citations }\end{array}$ & Main Goal \\
\hline [20] & 2004 & $\begin{array}{l}\text { Assessment of } \\
\text { productivity loss in } \\
\text { air-conditioned buildings } \\
\text { using PMV index }\end{array}$ & $\begin{array}{c}\text { Energy and } \\
\text { Buildings/4.867 }\end{array}$ & 235 & $\begin{array}{l}\text { Reports on the assessment of } \\
\text { productivity loss in } \\
\text { air-conditioned office buildings } \\
\text { using PMV index. }\end{array}$ \\
\hline [55] & 2005 & $\begin{array}{l}\text { Forecasting labor } \\
\text { productivity changes in } \\
\text { construction using the } \\
\text { PMV index }\end{array}$ & $\begin{array}{l}\text { International Journal } \\
\text { of Industrial } \\
\text { Ergonomics } / 1.662\end{array}$ & 59 & $\begin{array}{l}\text { Briefly describes and points out } \\
\text { the main deficiencies of three } \\
\text { models for predicting a } \\
\text { productivity/established } \\
\text { thermal environment. }\end{array}$ \\
\hline [56] & 2012 & $\begin{array}{l}\text { Towards productivity } \\
\text { indicators for } \\
\text { performance-based façade } \\
\text { design in } \\
\text { commercial buildings }\end{array}$ & $\begin{array}{c}\text { Building and } \\
\text { Environment/4.971 }\end{array}$ & 35 & $\begin{array}{l}\text { Presents the grounds for } \\
\text { establishing links between } \\
\text { occupant productivity and } \\
\text { combined effects of four IEQ } \\
\text { key aspects related to façade, } \\
\text { that is, thermal comfort, } \\
\text { auditory comfort, visual } \\
\text { comfort and air quality, in } \\
\text { occupant productivity. }\end{array}$ \\
\hline [57] & 2016 & $\begin{array}{l}\text { A computer model for the } \\
\text { assessment of employee } \\
\text { performance loss as a } \\
\text { function of thermal } \\
\text { discomfort or degree of } \\
\text { heat stress }\end{array}$ & $\begin{array}{l}\text { Intelligent Buildings } \\
\text { International/1.56 }\end{array}$ & 21 & $\begin{array}{l}\text { Presents an overview of } \\
\text { different researches and } \\
\text { researchers' attempts to derive a } \\
\text { mathematical link between } \\
\text { performance loss and } \\
\text { employees' thermal } \\
\text { (dis)comfort shown in the } \\
\text { sensation of } \\
\text { average temperature. }\end{array}$ \\
\hline [58] & 2017 & $\begin{array}{c}\text { Can self-evaluation } \\
\text { measure the effect of IEQ } \\
\text { on productivity? A review } \\
\text { of literature }\end{array}$ & Facilities/1.150 & 10 & $\begin{array}{l}\text { Examines self-evaluation } \\
\text { reliability as a method for } \\
\text { measuring the effect(s) IEQ on } \\
\text { office workers' productivity. }\end{array}$ \\
\hline [44] & 2017 & $\begin{array}{l}\text { A co-citation analysis on } \\
\text { thermal comfort and } \\
\text { productivity aspects in } \\
\text { production and } \\
\text { office buildings }\end{array}$ & Buildings & 12 & $\begin{array}{l}\text { The link between thermal } \\
\text { comfort and productivity in } \\
\text { workplaces is reviewed and } \\
\text { analyzed through a co-citation } \\
\text { analysis-that is, a factorial } \\
\text { analysis applied to mutual } \\
\text { citations of the more } \\
\text { relevant contributions. }\end{array}$ \\
\hline [59] & 2019 & $\begin{array}{l}\text { Influence of indoor } \\
\text { environmental quality on } \\
\text { human health and } \\
\text { productivity-A review }\end{array}$ & $\begin{array}{l}\text { Journal of Cleaner } \\
\text { Production/7.246 }\end{array}$ & 56 & $\begin{array}{l}\text { Reviews the state of art in } \\
\text { literature and establishes a } \\
\text { connection between the factors } \\
\text { which influence health and } \\
\text { productivity in any indoor } \\
\text { environment, be it residential } \\
\text { or commercial. }\end{array}$ \\
\hline
\end{tabular}

The study by Kosonen and Tan (2004) [20] shows that the performance related to the task is associated to the human perception of the thermal environment, which depends on temperatures. Various combinations of thermal factors such as air velocity, clothing thermal insulation, and metabolic rate, among others, can lead to values similar to PMV, making it beneficial to use the PMV equation to predict productivity loss due to changes in thermal conditions. Published in 2005, the work of Mohamed and Srinavin (2005) [55], besides pointing out the models' shortcomings, presents a fourth model for predicting productivity, 
developed by the authors, where productivity can be predicted as a result of the PMV index. The study by Jin et al. (2012) [56] focuses on the foundations to establish the links between productivity and aspects of IEQ as well as showing an approach and relation to quantify the quality of indoor environment. Published in 2016, Roelofsen (2016) [57] besides presenting an overview of different researches, also presents an only computer model and tool of a manageable project for a variety of areas. The aim of this computer model is to evaluate employee's performance loss due to thermal discomfort or degree of heat stress. The article by Rashied and Byrd (2017) [58] reviews and identifies the various restrictions to the suitability of measuring productivity, and also provides a view on the inadequacies and biases which are found in self-evaluation. The connection between thermal comfort and productivity in workplaces is pursued by Tarantini et al. (2017) [44]; the results indicate that comfortable indoor thermal conditions can have beneficial impacts on the well-being and on the productivity of employees, such as higher operational rates, lower production loss, fewer medical leaves, and reduction in costs related to health. Mujan et al. (2019) [59] establishes a connection between the factors that influence health and productivity on indoor environment quality, which is widely separated into up to eight main factors, the emphasis being given only to the factors that can be actively measured and controlled: thermal comfort, indoor air quality and ventilation, visual comfort, and acoustic comfort.

\subsection{Ways of Assessing Productivity}

There is much criticism on the need of generalization to improve real procedures when evaluating productivity in organizations [60,61]. Occupant's productivity can be measured: physiologically, objectively, or subjectively [32]. Physiological measurements involve monitoring the indicators of the cardiovascular system, the respiratory system, the nervous system, and biochemistry. The main limitations are: (1) sensitivity of physiological indicators such as blood pressure to potential conditions for contamination such as room temperature, are very high. Therefore, to obtain reliable data, one needs an extremely stable and highly controlled experimental environment; and (2) the measurements themselves are intrusive and tend to affect the subject's normal performance [32]. Table 4 presents the kind of research used in the studies which were analyzed for this research.

Table 4. Performance/productivity assessment.

\begin{tabular}{cl}
\hline Ref. & Performance/Productivity Assessment \\
\hline$[7,14,40,62-72]$ & Subjective assessment. \\
\hline$[38,43,73-75]$ & Physiological/subjective assessment. \\
\hline$[76,77]$ & Subjective/experimental assessment. \\
\hline$[39,78,79]$ & Physiological/subjective/self-reported assessment. \\
\hline$[41]$ & Body measurements/physiological measurements/subjective assessment/objective (performance and learning tests). \\
\hline$[80]$ & Subjective/Absenteeism/Presenteeism Assessment. \\
\hline$[81]$ & Decrease in productivity/financial loss. \\
\hline$[82,83]$ & Subjective assessment/self-reported productivity. \\
\hline$[9,76,84]$ & Physiological/subjective/objective assessment (tests). \\
\hline$[85-94]$ & Subjective/objective assessment (tests). \\
\hline$[42,95,96]$ & Objective assessment (performance tests). \\
\hline$[48,82,97,98]$ & Physiological/objective assessment (performance tests). \\
\hline$[99]$ & Subjective assessment/estimated decrease in productivity. \\
\hline$[100]$ & Body measurements/subjective assessment. \\
\hline$[101]$ & Field measurements. \\
\hline$[102]$ & Physical measurements. \\
\hline$[103,104]$ & Data analysis. \\
\hline
\end{tabular}


In subjective assessment, occupants' feedback on changes in the physical environment can be gathered by means of field research (interviews and questionnaire) and objective assessments (calculations and metrics) [98]. Objective measurements are usually a measure for task performance, including the performance of the primary task (one only task is accomplished and productivity is measured as its absolute number) and comparative task performance (two or more tasks are consequently done and productivity variations between tasks are registered [98].

Commonly adopted productivity measures include performance tasks [24,31,105-108], self-perceived productivity $[50,58,109]$, and absenteeism [80]. The validity of these measures was questioned, since mock performance tasks may not reflect realistically the real work in workplaces [50,106,107]; self-perceived productivity may not reflect real productivity $[24,58,109]$.

Subjective measures, which aim at obtaining occupants' perception about the level of productivity by means of interviews and questionnaires, has been gaining strength since people tend to act according to their feelings [110]. However, occupants' self-evaluated performance may be influenced by their subjective cognition. Therefore, it is necessary to combine objective and subjective methods in order to evaluate performance at work [77].

In the articles which were analyzed, it was noted that the majority uses subjective and/or a combination of measures, as well as physiological and physical measurements to assess productivity. Roughly $70 \%$ of the studies use subjective evaluation and approximately $10 \%$ of the studies use performance self-evaluation which, according to [58], does not measure with precision occupants' performance. It was further noted that the vast majority of studies are based on hypotheses and that research done through experiments are relatively limited by very small samples or by environmental factors or insufficient number of people.

\section{Discussion}

This section presents and discusses the results of this review according to the research questions.

\section{RQ1. Which indoor environmental quality parameters are taken into account when evaluating productivity?}

The topic related to thermal environment and occupant productivity has earned notoriety most probably after the emergence of the concept of indoor environmental quality (IEQ) [111]. IEQ involves several factors such as light, thermal comfort, vibration, and the individual's emotional and psychological needs. A comfortable indoor environment can effectively reduce the occupants' complaints and improve work productivity, which is of great importance in promoting economic development [80]. Among these factors, thermal comfort has the greatest influence in occupants' comfort and productivity $[112,113]$. The analysis of the factors found in the 60 articles and IEQ parameters can be found in Table 4 .

Considering factor analysis, Table 5 shows that out of the 60 analyzed articles, about $90 \%$ used temperature as one of the factors to evaluate the level of thermal comfort, satisfaction, and productivity. Some of these studies still use temperature and other combined factors such as: humidity, air quality, sound, light and $\mathrm{CO}_{2}$, which are IEQ parameters.

Table 5. Parameters used in research.

\begin{tabular}{cl}
\hline Ref. & \multicolumn{1}{c}{ IEQ Factors Used in Research } \\
\hline$[7]$ & Conditions for temperature, with constant mechanical wind (CMW) and simulated natural wind (SNW). \\
\hline$[9,39,41,43,64,66,68,70,77,95,97,98,100]$ & Air temperature. \\
\hline$[74]$ & Different levels of WBGT (wet-bulb globe temperature) using PMV productivity model. \\
\hline$[78]$ & Unique temperature experimental factors, relative humidity and fresh air (100\% outdoor air). \\
\hline$[80]$ & Air temperature and relative humidity, mean radiant temperature and air velocity. \\
\hline$[76]$ & Measurement of weather parameters for evaluating PMV and PPD indexes. \\
\hline
\end{tabular}


Table 5. Cont.

\begin{tabular}{|c|c|}
\hline Ref. & IEQ Factors Used in Research \\
\hline [81] & $\begin{array}{l}\text { Performance of two control methods-conventional setting check point and control based on predicted } \\
\text { mean vote (PMV). }\end{array}$ \\
\hline [41] & Velocity, thermal comfort. \\
\hline [62] & Thermal comfort. \\
\hline [63] & Air temperature, air velocity, relative humidity and time of day. \\
\hline [84] & Global temperature compared to air temperature. \\
\hline [85] & Indoor temperature, indoor air quality, both natural and artificial light. \\
\hline [86] & Both concentrations of $\mathrm{CO}_{2}$ and IAQ are considered. \\
\hline [87] & Thermal/ventilation sensation. \\
\hline [65] & Indoor temperature, humidity, air quality, natural and artificial light and sound levels. \\
\hline [88] & Customized ventilation (PVS), controlling the placement of air terminal device and rate of air flow. \\
\hline [79] & Temperature, light and ventilation rate. \\
\hline [42] & Air temperature, related humidity, operative temperature and air velocity (PMV scale) standard. \\
\hline [67] & $\begin{array}{l}\text { Effects of critical factors of the built environment on the occupants of commercial buildings with } \\
\text { green certification. }\end{array}$ \\
\hline [38] & Temperature, humidity and air velocity. \\
\hline [40] & Predicted mean vote, $\mathrm{CO}_{2}$, personal factor. \\
\hline [89] & Condition of air supply, supply temperature and environment temperature. \\
\hline [90] & Relative humidity. \\
\hline [96] & IEQ effect (thermal, light and color layout). \\
\hline$[69,75]$ & Indoor parameters (temperature and air quality). \\
\hline [91] & Customized ventilation. \\
\hline [93] & $\begin{array}{l}\text { Perceptions of thermal comfort, indoor air quality, light and acoustic environment. Simulated office tasks } \\
\text { were carried out to assess productivity. }\end{array}$ \\
\hline$[71,94]$ & Microclimate conditions. \\
\hline [99] & $\begin{array}{l}\text { Thermal energy use, } \mathrm{CO}_{2} \text { emissions from the use of electricity and productivity loss due to } \\
\text { thermal discomfort. }\end{array}$ \\
\hline [83] & Thermal satisfaction/self-reported productivity. \\
\hline$[14,72,82,92]$ & Indoor environmental quality (IEQ). \\
\hline [48] & Temperature, ventilation rate, sound level. \\
\hline [101] & Thermal stress/temperature. \\
\hline$[102,103]$ & Temperature and relative humidity. \\
\hline$[104]$ & Subjective data of thermal sensation and objective measurements. \\
\hline
\end{tabular}

RQ2. Is there a thermal condition which is considered ideal for increasing productivity?

Many studies have been carried out showing that temperature has a significant effect on performance $[7,19,37,48,66]$, among others. The results of the main studies are shown here below.

Kosonen and Tan (2004) [19] reported that maximum performance occurs when the predicted mean vote (PMV) is -0.21 at a temperature of $20^{\circ} \mathrm{C}$ with a clo value (1.16 clo). Seppänen, Fisk, and Lei (2006) [37] analyzed data obtained from studies with objective measurements of productivity such as speed and precision in different tasks. The data obtained from these studies were used to evaluate the change in productivity with the change in temperature. The results show that productivity increases up to $22{ }^{\circ} \mathrm{C}$ and starts to decrease above $24-26^{\circ} \mathrm{C}$. In addition, the study reports a percentage reduction in productivity as the temperature rises. According to Tsutsumi et al. (2007) [90], the positive effects of low humidity on subjective pleasantness were found in transitory conditions of low humidity due to greater vaporisation from the human body, while no significant 
difference in thermal sensation and in the humidity sensation within four levels of relative humidity was obtained. The subjective performance was found to be on the same level in all conditions. A condition for satisfactory thermal comfort for office employees can be reached with temperatures from air-conditioning systems at $26-28^{\circ} \mathrm{C}$ in the mornings and at $24-26^{\circ} \mathrm{C}$ in the afternoon and at night. These temperature setting ranges help to maintain and improve employees' productivity in the office in the morning periods (18\%), afternoon (1\% to 15\%) and evening (7\%) (Ngarmpornprasert and Koetsinchai, 2010) [63]. According to Kekäläinen et al. (2010) [69], the percentage of dissatisfied people and neural behavioural systems with air quality increased and self-estimation on work efficiency decreased considerably with temperatures above $25^{\circ} \mathrm{C}$.

Lan et al. (2011) [48] carried out a study on three temperature levels $\left(17^{\circ} \mathrm{C}, 21^{\circ} \mathrm{C}\right.$, and $28^{\circ} \mathrm{C}$ ) and discovered that neurobehavioral performance decreased when the thermal environment deviated from the neutral condition, and people had more negative emotions and needed to make more effort to keep up their performance in an environment of thermal discomfort. It is recommended that the PMV (predicted mean vote) range for overall comfort be from -0.5 to 0.5 in the standard ASHRAE 55 [18]. Lan et al. (2011) [48] suggest that the comfort zone range in workplaces must be between -0.5 and 0 to avoid performance loss.

Cui et al. (2013) [7] assessed human performance in dynamic environments with air flux from neutral to slightly hot and did not report any significant change in performance in all three simulated tasks (pattern matching, memory addition and memory typing). According to Maula et al. (2016) [66], performance in memory task working at $29^{\circ} \mathrm{C} \mathrm{com-}$ pared to $23{ }^{\circ} \mathrm{C}$ was negatively affected, while the psychomotor capacities, work memory, attention, and long-term memory were not affected. The noted performance was also not affected by the temperature. Sarbu and Pacurar (2015) [76] noted that the maximum performance is obtained at an air temperature of $27^{\circ} \mathrm{C}$ in the cooling season. The student's performance shows an insignificant reduction of $0.6 \%$, even with an increase of $\mathrm{CO}_{2}$. Liu et al. (2017) [75] noted that being exposed to $35^{\circ} \mathrm{C}$ increased health symptoms and discomfort reduced performance.

Results from the studies of Zangh and Dear (2017) [39] confirmed that simpler cognitive tasks are less vulnerable to heat than more complex tasks. According to Geng et al. (2017) [93], ideal productivity was reached when people felt "neutral" or "slightly cold". The increase in thermal satisfaction had a positive effect on productivity. Productivity loss appeared together with thermal discomfort caused by very high or very low air temperature. Most participants felt "neutral" and were satisfied with the office thermal environment at $24^{\circ} \mathrm{C}$.

Fahed et al. (2018) [74] noted that the results of the study with furnace workers exposed to more thermal stress than others (WBGT $=31.35,31.32$ and $31.34^{\circ} \mathrm{C}$ ) revealed that thermal labor conditions and air pollution have a considerable impact on workers' health and performance. According to Hong et al. (2018) [86], when operative temperature is altered from $18.70^{\circ} \mathrm{C}$ (cold) to $25^{\circ} \mathrm{C}$ (neutral), the best task performance score is calculated.

In a real office environment in the tropics, increasing the temperature set point from

$23{ }^{\circ} \mathrm{C}$ to $26^{\circ} \mathrm{C}$, at the same time in which we supply the occupants with shared control over ceiling ventilators, we can obtain a considerable increase in thermal comfort (that is, thermal acceptability increases $59-92 \%$ ), keeping a high vigilant state, capacity for concentration and self-related productivity [83].

The influence of temperature on learning performance test varied significantly and depended mainly on the kind of task. The results indicated that thermal discomfort caused by high or low temperatures negatively influenced the performance of students during learning. A qualitative and quantitative connection was established between temperature and the students' learning performance. In addition, the temperature for ideal performance is approximately $14{ }^{\circ} \mathrm{C}$, with an average relative performance of $99.4 \%$ [100]. The ideal air temperature for performance is $28{ }^{\circ} \mathrm{C}$, with $104.8 \%$ [103] being the relative learning 
performance. The ideal performance occurred when thermal sensation vote was neutral and total thermal discomfort was obtained with temperatures above $28^{\circ} \mathrm{C}$ [43].

Low and high temperatures $\left(18^{\circ} \mathrm{C}\right.$ and $\left.28^{\circ} \mathrm{C}\right)$ can cause performance loss at work. Compared to $18{ }^{\circ} \mathrm{C}$ and $28^{\circ} \mathrm{C}$, temperatures from $20^{\circ} \mathrm{C}$ to $26^{\circ} \mathrm{C}$ showed that more people reported work as being neutral (0); and fewer people reported low performance in these conditions (-2). Although temperature did not significantly influence performance in the three perception tests, it had a significant effect in the overall perception task performance [75]. Wang et al. [73] reported that with higher air velocity, learning performance dropped and did so at a higher rate in an environment at $26^{\circ} \mathrm{C}$ than in an environment at $29^{\circ} \mathrm{C}$. According to Kaushik et al. (2000) [62], temperature has a highly positive effect on the occupants when it varies from $22^{\circ} \mathrm{C}$ to $24.5^{\circ} \mathrm{C}$ and a positive effect when it varies from $21^{\circ} \mathrm{C}$ to $25^{\circ} \mathrm{C}$.

After beginning the work, many differences were noted on the effect of temperature on occupant performance/productivity. This can be related to differences in studies on the type of work. The studies present great differences as they evaluate work in manufacturing industries as well as hand labor, and therefore performance/productivity is quite distinct; professional and cognitive performance need different evaluation methods [77].

Therefore, analyzing the existence of a more productive thermal condition based on selected studies seems to confirm that performance/productivity can be obtained in a more ample temperature range and depends on other factors such as activity and personal factors.

RQ3. Taking several studies into account on the connection between thermal comfort and productivity, how can productivity be calculated?

Currently, there is no standard for measuring productivity and it is not easy to measure thermal effect on human performance in workplaces as there are many variables related to specific tasks in specific contexts that cannot be properly computed [50]. It is necessary to combine objective and subjective methods to evaluate performance at work [77].

Arithmetic relations have been put forward by different researchers to quantify the decrease in productivity in percentages according to the deviation of ambient temperature (or thermal sensation) from a more adequate temperature. This study analysed 60 articles, of which 20 were selected through mathematical formulas to calculate productivity. Table 6 lists key journals where it was possible to find an equation to calculate productivity.

In the analyzed studies, it was noted that several mathematical formulas are used to determine productivity. This must be due to probable differences between IEQ variables and factors used in the studies. In addition, of the 60 studies analyzed, only 20 presented mathematical formulas to evaluate productivity. 
Table 6. Performance/productivity calculation.

\begin{tabular}{|c|c|c|c|c|}
\hline Ref. & Year & Description & Productivity Calculation & Eq. \\
\hline \multirow{2}{*}{ [102] } & \multirow{2}{*}{1985} & $\begin{array}{c}\text { Equation (1) where } P_{\mathrm{c}} \text { is productivity factor for cool and cold related to productivity with air temperature }\left(\mathrm{T}_{\mathrm{a}}\right) \text { and relative } \\
\text { humidity }\left(R_{\mathrm{h}}\right) \text {, to be used in cold climate and applicable from }-29 \text { to } 10^{\circ} \mathrm{C} \text {. }\end{array}$ & $\begin{array}{l}P_{\mathrm{c}}=0.0144 \cdot \mathrm{T}_{\mathrm{a}}-0.00313 \cdot R_{\mathrm{h}}-0.000107 \cdot\left(\mathrm{T}_{\mathrm{a}}\right)^{2}-0.000029 \cdot\left(R_{\mathrm{h}}\right)^{2}-0.0000357 \\
\left(\mathrm{~T}_{\mathrm{a}} \cdot R_{\mathrm{h}}\right)+0.647\end{array}$ & (1) \\
\hline & & $\begin{array}{c}\text { Equation (2) } P_{\mathrm{w}} \text { is productivity factor for heating or hot, } \mathrm{T}_{\mathrm{a}} \text { air temperature in degrees Fahrenheit, and } R_{\mathrm{h}} \text { is relative humidity, } \\
\text { expressed in percentages, to be used in hot climates and is applicable from } 21 \text { to } 49^{\circ} \mathrm{C} \text {. }\end{array}$ & $P_{\mathrm{w}}=0.0517 \cdot \mathrm{T}_{\mathrm{a}}+0.0173 \cdot R_{\mathrm{h}}-0.00032 \cdot\left(\mathrm{T}_{\mathrm{a}}\right)^{2}-0.0000985 \cdot\left(R_{h}\right)^{2}-0.0000911 \cdot\left(R_{\mathrm{h}}\right)-1.459$ & (2) \\
\hline \multirow{2}{*}{ [103] } & \multirow{2}{*}{1987} & \multirow{2}{*}{$\begin{array}{l}\text { Equation (3) where PR is the relation of predicted daily performance (real/expected), } \mathrm{T}_{\mathrm{a}} \text { is air temperature at } 13 \mathrm{~h} \text { expressed } \\
\text { in percentage. Equation (3) is limited and to deduct climate effects, one needs to acknowledge that predicted crew efficiency } \\
\text { is inversely related to PR, as shown in Equation (4). }\end{array}$} & $\mathrm{PR}=9.448+0.0518 \cdot \mathrm{T}_{\mathrm{a}}-2.819 \cdot \ln \left(\mathrm{T}_{\mathrm{a}}\right)+3.89 \times 10^{-37} \cdot e^{R h}$ & (3) \\
\hline & & & Predict efficiency $(E)=1 / P R$ & $(4)$ \\
\hline [71] & 2003 & $\begin{array}{l}\text { Use the Toftum e Friis-Hansen (2009) model where } R P=\text { relative performance, tsv = average thermal sensation according to } \\
\text { ASHRAE seven-point scale (ASHRAE 1997). }\end{array}$ & $\mathrm{RP}=0.9945-0.0123 \cdot \mathrm{tsv}-0.0069 \cdot \mathrm{tsv}^{2}$ & \\
\hline \multirow{2}{*}{ [99] } & \multirow[t]{2}{*}{2003} & \multirow{2}{*}{$\begin{array}{l}\text { The percentage of productivity loss } \mathrm{D} \text { of an office employee can be expressed by the combination of productivity losses in } \\
\text { reasoning tasks } T_{\mathrm{k}} \text { and typing tasks } T_{\mathrm{p}} \text { with a reasoning rate for general tasks } \alpha \text {, where } T_{\mathrm{k}} \text { and } T_{\mathrm{p}} \text { measured in laboratory } \\
\text { environments were correlated to the occupant's preferred average thermal sensation vote } \gamma_{1} \text { varying between }-0.21 \text { and } 1.28 \text {. }\end{array}$} & $T_{\mathrm{k}}=1.5928 \cdot \gamma 15-1.5526 \cdot \gamma 14-10.401 \cdot \gamma 13+19.226 \cdot \gamma 12+13.389 \cdot \gamma 1+1.8763$ & (6) \\
\hline & & & $\begin{array}{l}T_{p}=-60.543 \cdot \gamma 16+198.41 \cdot \gamma 15-183.75 \cdot \gamma 14-8.1178 \cdot \gamma 13+50.24 \cdot \gamma 12+32.123 \\
\gamma 1+4.8988\end{array}$ & (7) \\
\hline \multirow[b]{2}{*}{ [19] } & \multirow[b]{2}{*}{2004} & \multirow{2}{*}{$\begin{array}{l}\text { Using the mathematical expression of productivity loss, } y=c_{0}(\mathrm{PMV})+c_{1}(\mathrm{PMV})^{2}+c_{2}(\mathrm{PMV})^{3}+c_{3}(\mathrm{PMV})^{4}+\cdots+c_{n} \\
(\mathrm{PMV})^{n} \text {, Equations }(8) \text { and }(9) \text { are derived to typing and reasoning tasks respectively. } \\
\text { Kosonen and Tan (2004) published two connections for typing performance loss and thought due to the average temperature } \\
\text { sensation based on the research by Wyon et al. (1975), where: } P=\text { performance loss }(\%) ; P \geq 0 \\
\text { tsv }=\text { average thermal sensation according to seven-point scale ASHRAE (ASHRAE 1997). }\end{array}$} & $\mathrm{y}=-0.543 \cdot x^{6}+198.41 \cdot x^{5}-183.75 \cdot x^{4}-8.1178 \cdot x^{3}+50.24 \cdot x^{2}+32.123 \cdot x+4.8988$ & $(8)$ \\
\hline & & & $\begin{array}{r}\mathrm{y}=1.5928 \cdot x^{5}-1.5526 \cdot x^{4}-10.401 \cdot x^{3}+19.226 \times 2 x^{2}+13.389 \cdot x+1.8763 \\
\text { Typing } P=4.8988+32.123 \cdot \mathrm{tsv}+50.24 \cdot \mathrm{tsv}^{2}-8.1178 \cdot \mathrm{tsv}^{3}-183.75 \cdot \mathrm{tsv}^{4}+198.41 \cdot \mathrm{tsv}^{5} \\
\text { Reasoning } P=1.8763+13.389+19.226 \cdot \mathrm{tsv}^{2}-10.401 \cdot \mathrm{tsv}^{3}-1.5526 \cdot \mathrm{tsv}^{4}+1.5928 \cdot \mathrm{tsv}^{5}\end{array}$ & (9) \\
\hline \multirow{2}{*}{ [55] } & \multirow{2}{*}{2005} & \multirow{2}{*}{$\begin{array}{l}\text { Three different mathematical regression models represented by Equations (10)-(12) to predict productivity for light, moderate } \\
\text { and heavy construction tasks respectively (Srinavin, 2002). The tree equations are applicable to temperature range } \\
\text { from } 5 \text { to } 45^{\circ} \mathrm{C} \text {. }\end{array}$} & $\mathrm{PL}=102-0.80 \cdot \mathrm{PMV}-1.84 \cdot(\mathrm{PMV})^{2}$ & (10) \\
\hline & & & $\mathrm{PH}=83+21.64 \cdot \mathrm{PMV}-9.53 \cdot(\mathrm{PMV})^{2}+0.91 \cdot(\mathrm{PMV})^{3}$. & $(12)$ \\
\hline [81] & 2007 & $\begin{array}{l}\text { The yearly average productivity loss of an office occu-pant is determined by Equation }(13) \text { where } P_{a v g, j} \text { is the yearly average } \\
\text { productivity loss of a joccupant where j goes from } 1 \text { to } 19 \text {, representing all the office occupants. The proportion of a } \\
\text { mechanical task and the proportion of a purely mental task are associated to degree } i \text {, denoted by } \alpha_{i, t y p} \text { and }\left(1-\alpha_{i, t y p}\right) \\
\text { respectively } P_{m, t} \text { is the PMV for the occupant in an instant of time t in one month } \mathrm{m} \text {. The duration of time T1 and T2 } \\
\text { represents commercial time. }\end{array}$ & $\left.P_{\text {avg.j }}=\frac{1}{365} \sum_{m=5}^{10}\left\{\frac{L m}{T 2-T 1} \int_{T 1}^{T 2}\left[\alpha_{i . t y p} P L_{t y p} P_{(m t)}+\left(1-\alpha_{i . t y p}\right) P L_{\text {think }} P_{m . t}\right)\right] d t\right\}$ & (13) \\
\hline [70] & 2007 & $\begin{array}{l}\text { Normal performance was calculated from Equation (14), where } x_{A, i}=\text { number of correct answers during session } i \text { for the } \\
\text { subject; } A=\text { average number of correct answers from subject } A \text { throughout all the sessions. }\end{array}$ & $S_{A, i}=\frac{\left(x_{A, i}-\bar{x}_{A}\right)}{S_{A}} \times 10+50$ & (14) \\
\hline [104] & 2009 & $\begin{array}{c}\text { Jensen, Toftum and Friis-Hansen (2009) relation where } \mathrm{RP}=\text { relative performance; tsv = average thermal sensation, according } \\
\text { to the seven-point scale AHRAE (ASHRAE 1997). }\end{array}$ & $\mathrm{RP}=0.9945-0.0123 \cdot \mathrm{tsv}-0.0069 \cdot \mathrm{tsv}^{2}$ & \\
\hline [98] & 2009 & $\begin{array}{l}\text { Performance loss } \\
\text { Equations by work category for the situation WBGT } \geq 34 \text {. According to the research by Zhao, Zhu e Lu (2009), the concept of } \\
\text { 'heat tolerance time' is important only in the case of WBGT } \geq 34 \text { where Thht }=\text { heat tolerance time }(\mathrm{h}), P_{\text {wbgt }}=\text { performance } \\
(\%) ; t \leq \text { Thtt. }\end{array}$ & 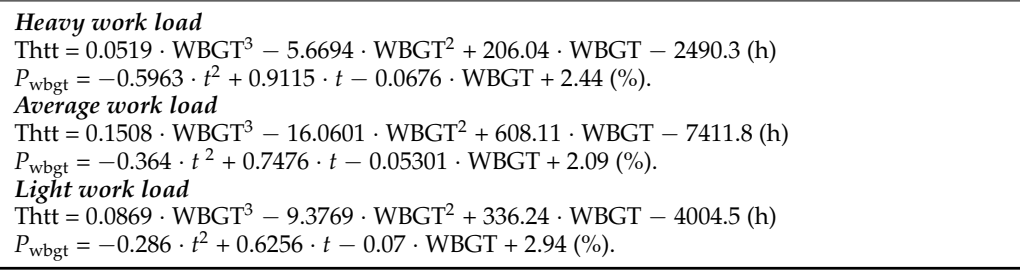 & \\
\hline
\end{tabular}


Table 6. Cont.

\begin{tabular}{|c|c|c|c|c|}
\hline Ref. & Year & Description & Productivity Calculation & Eq. \\
\hline [63] & 2010 & $\begin{array}{l}\text { Percentage in change in productivity of a topic under implementation of each task was calculated from Equa-tion (15) } \\
\text { where:Chang } e_{i j k} \text { productivity change of a task } j \text { done by subject } i(\%), \bar{x}_{i j} \text { : amount of work done by subject } i \text { for task } j x_{i j} \text { : } \\
\text { subject's } i \text { average performance for task } j .\end{array}$ & $\begin{array}{l}\text { Change } i_{i j k}=\left(x_{i j k}-\bar{x}_{i j}\right) / \bar{x}_{i j} \times 100 \\
\text { i: subject } 1 \text {. subject } 2 \text {. subject } 3 \text { and subject } 4 \\
\text { j: typing task. calculation task. review task. simple reaction task and reaction to color stimuli } \\
\text { k: experiment number }\end{array}$ & (15) \\
\hline \multirow[t]{2}{*}{ [76] } & \multirow[t]{2}{*}{2015} & \multirow{2}{*}{$\begin{array}{l}\text { Correlation between school performance } \eta_{t, K} \text { and indoor air temperature Equation }(16) \text {. Using the average of results } \\
\text { obtained by all students in each of the } 12 \text { tests } P \text {, Gaussiana correlation between performance } \eta_{t, P} \text { and air temperature } t_{i} \text {, } \\
\text { Equation (17). was deducted. The correlation to estimate partial performance } \eta_{R H} \text { depending on relative humidity } R H_{i} \text { was } \\
\text { obtained in a similar way Equation (18). }\end{array}$} & $\eta_{t . P}=93.5 \cdot \exp \left(-\frac{(t i-27.902)^{2}}{743.591}\right)$ & (17) \\
\hline & & & $\eta_{R H}=90.33 \cdot \exp \left(-\frac{(R H i-60.79)^{2}}{7504.75}\right)$ & (18) \\
\hline [74] & 2018 & $\begin{array}{l}\text { Productivity loss was estimated using the Kjellstrom et al. (2009) method. To determine the conditions for thermal comfort, } \\
\text { Equation (19) represents the percentage of productivity from heavy work load where } P_{H} \text { means the value of productivity for } \\
\text { heavy work load. }\end{array}$ & $P_{H}=83+21.64 \cdot \mathrm{PMV}-9.53 \cdot(\mathrm{PMV})^{2}+0.91 \cdot(\mathrm{PMV})^{3}$ & (19) \\
\hline [86] & 2018 & $\begin{array}{l}\text { The performance of tasks by the occupants of the build-ing was divided into six tasks. In this case, standardi-zation of values } \\
\text { corresponding to each attribute was carried out using Equation (20), where SA is the stand-ardized value for } Z_{A} \text { and } Z_{A} \text { is } \\
\text { each attribute. }\end{array}$ & $\mathrm{S}_{\mathrm{A}}=\left(\mathrm{Z}_{A}-\mathrm{Z}_{\text {Amin }}\right) /\left(\mathrm{Z}_{\text {Amax }}-\mathrm{Z}_{\text {Amin }}\right)$ & (20) \\
\hline [84] & 2019 & $\begin{array}{l}\text { Mathematical model using the linear model (GLM) to examine the behavior of (tg - ta) and trm in cognitive performance (Dt } \\
\text { index-overall performance as a function of time) of students Equation ( } 21) \text {, where: } 1 \text {. Probability distribution of } Y(\mathrm{Dt}), \mathrm{Y} \sim \mathrm{N} \\
(\mathrm{\sigma} 2) ; 2 \text {. The function which connects the expected value } \mathrm{Y}(\mathrm{Dt}) \text { with a linear combination of the explanatory variant. }\end{array}$ & $E(D t)=\beta 0+\beta 1 \cdot$ trm $+\beta 2 \cdot \operatorname{tg}-\operatorname{ta}$ & (21) \\
\hline [64] & 2019 & $\begin{array}{l}\text { Ordinary least square regression (OLS) to map the link between temperature and performance, Equation (22): where } i \text { refers } \\
\text { to an individual, } j \text { refers to an experimental session, Temp } p_{j} \text { is the room temperature during session } j \text { and } X_{i j} \text { is a vector of } \\
\text { observable characteristics of the individual and the session which can influence performance. The dependent variable } Y_{i j} \text { is a } \\
\text { measure of the individual's performance i in the mathematical task, verbal task, CRT, and a measure of total amount of } \\
\text { attempted answers. }\end{array}$ & $Y_{i j}=\alpha+\beta \cdot \operatorname{Temp}_{j}+X_{i j Y}+\epsilon_{i j}$ & (22) \\
\hline \multirow{2}{*}{ [40] } & \multirow{2}{*}{2019} & \multirow{2}{*}{$\begin{array}{l}\text { The relation between productivity, } \mathrm{CO}_{2} \text { concentration and personal factors, combined, where } \mathrm{Z} \text { represents productivity, } x \\
\text { represents PMV and } y \text { represents } \mathrm{CO}_{2} \text { concentration; coefficients } \mathrm{a}, \mathrm{b}, \mathrm{c}, \mathrm{d}, \mathrm{e}, \mathrm{f}, \mathrm{g}, \mathrm{h}, \mathrm{i}, \mathrm{j} \text { and } \mathrm{k} \text { are obtained by means of } \\
\text { a software. }\end{array}$} & Productivity $=\mathrm{f}\left(\mathrm{PMV} \cdot \mathrm{CO}_{2}\right)$ & (23) \\
\hline & & & $\mathrm{Z}=\mathrm{a}+\mathrm{b} \cdot \mathrm{x}+\mathrm{c} \cdot x^{2}+\mathrm{d} \cdot x^{3}+\mathrm{e} \cdot x^{4}+\mathrm{f} \cdot x^{5}+\mathrm{g} \cdot \mathrm{y}+\mathrm{h} \cdot y^{2}+\mathrm{i} \cdot y^{3}+\mathrm{j} \cdot y^{4}+\mathrm{k} \cdot y^{5}$ & $(24)$ \\
\hline [101] & 2020 & Equation for estimating performance decline at work can be written as Equation (25): & $\mathrm{P}(\%)=2 \times\left(\right.$ Thermal stress. $\left.{ }^{\circ} \mathrm{C}\right)-50$ & (25) \\
\hline \multirow[t]{2}{*}{ [78] } & \multirow[t]{2}{*}{2020} & \multirow{2}{*}{ 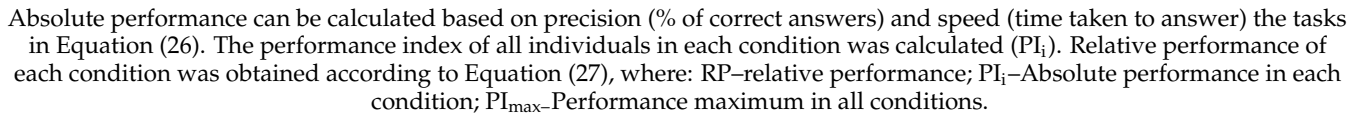 } & $\mathrm{PI}=\left(\text { precision of }^{0.5} \text { speed }^{0.5}\right)^{2}=$ speed precision & (26) \\
\hline & & & $\mathrm{RP}=\mathrm{PI}_{\mathrm{i}} / \mathrm{PI}_{\max } \times 100$ & (27) \\
\hline
\end{tabular}




\section{Future Trends and Gap Researches}

From what was presented in this article, emphasis is given to the contribution of the results towards an overall view of publications related to thermal comfort, more specifically in the sense of highlighting the main researches on the link between thermal comfort and productivity.

The review carried out determined that:

(a) there are still very few studies that provide us with ways of calculating productivity,

(b) there are few articles that discuss all the IEQ and personal factors which are necessary to calculate productivity.

Due to the importance of the subject matter, it is necessary that researches of this nature be carried out in order to define standards for determining occupant productivity, with different kinds of activities that take into account all the factors involved. In the analyzed articles, it was noted that there are still thermal and personal factors which have not been satisfactorily studied.

From analyzing the articles, this research adds that (a) the majority of analyzed studies are subjective and/or a combination of methods to evaluate productivity; and (b) most articles deal with few factors to understand this gap. The complexity of the work must also be evaluated. Therefore, all aspects must be considered: personal, social, environmental, or organizational. In addition to IEQ factors, it was observed that in a few analyzed studies, demographic characteristics (for example, nationality, age, and gender), are important motivators of occupants' personal characteristics in the way they perceive their environment and report their levels of satisfaction, influencing comfort, satisfaction and productivity. Andargie et al. (2019) [114] points out that demographic factors such as sex and are significant determiners of the majority of studied comfort measurements and performance. Gender is considered an important factor in productivity, for the fact that women generally prefer higher indoor temperatures than men is widely supported by research evidence.

Results show that within a temperature range from 16 to 33 degrees Celsius, women usually show better cognitive performance in the hotter extreme of temperature distribution, while men do better in colder temperatures. The increase in female cognitive performance seems to be largely driven by an increase in the number of answers sent. In the same way, the decrease in male cognitive performance is partially driven by a decrease in observable effort. It is important to emphasize that the increase in female cognitive performance is greater and more precisely estimated than the decrease in male performance [64]. The male occupants and the younger generations also considered the office environment as having a negative impact on perceived productivity in the workplace, compared to female and older occupants [115]. The fact that women generally prefer higher indoor temperatures than men is firmly sustained by research evidence $[109,116]$. This difference in preferences, sometimes called "the battle of the thermostat", is often discussed in popular culture and has gained considerable attention from the media. [117,118].

The thermal sensational of the elderly is usually 0.5 scale units (in a thermal sensation scale of 7 points) lower than the thermal sensation of younger adults. During a constant temperature level and the same level of clothing, the elderly prefers higher room temperatures compared to younger people, which is in accordance with previous studies [68]. According to Wu et al. (2020) [78], many middle-aged people work in offices and whose physical and mental state is different from the younger occupants as they can have different thermal sensations while being in the same environment. One of the critical points in evaluation is exactly the lack of protocols for measuring productivity. It is practically impossible to compare results of different researches due to different indoor and outdoor conditions in which they are done. Productivity can involve many dimensions apart from performance itself, for example, social factors such as business and social ones, the relationship with colleagues; organizational factors such as organizational structure, safety at work, workload, management; and personal factors such as lesions, sleep loss, events in one's life, health/wellness and financial stress, just to mention a few $[3,107,119]$. 
For future studies, one recommends considering all IEQ factors and map out the occupants' profiles (details such as nationality, age and gender) to help in understanding the profile of occupants' thermal comfort, which is still not studied enough. The analysis of personal factors presented in the study seems to affect performance/productivity, as well as cognitive abilities. There are factors, such as school level, abilities, and emotional states, among others, which must be considered.

A new feasible manner of relating thermal comfort to productivity is through APD index (Actual Percentage of Dissatisfied), which considers the actual thermally dissatisfied subjects with their environment. The original model PMV/PPD proposed by Fanger considers that when people vote 0 on a scale of 7 points (neutral), there will be a total of $5 \%$ thermally dissatisfied people with the environment. Researches, however, has shown that the PMV index underestimates or overestimates people's thermal sensation. If, in an environment, many people vote +3 and -3 on a scale of seven points, the average will be 0 , and this will not present the real aspect of this environment. Other researches already use APD instead of the traditional PPD [120,121].

Broday and Xavier (2020) [122] verified that the real dissatisfied subjects can reach up to $50 \%$ of people with sedentary activities in an office, even if the average votes are 0 , which differs from $5 \%$ of the original Fanger model. By means of PROBIT statistical analysis, all those who voted differently to 0 on a scale of 7 points were considered dissatisfied with the environment. Some studies shown in Table 6 relate productivity with PMV or TSV. This revision did not find studies which show how productivity is related to real thermally dissatisfied subjects. In this way, this research is going to study the connection "Productivity $=f(\mathrm{TSV}, \mathrm{APD})$ " to verify in what way real conditions affect productivity. This analysis will enable to verify which number of dissatisfied subjects better represents an environment taking real votes into account on thermal sensation reported by users.

\section{Conclusions}

This article proposes three research questions. When answering RQ1, it is shown that roughly $90 \%$ of the analyzed studies use temperature as one of the factors for analyzing productivity. Some of these studies use temperature and other combined factors such as: humidity, air quality, and $\mathrm{CO}_{2}$. However, some factors are not widely pursued. The answer to RQ2, on the other hand, shows that there is not only one ideal thermal condition to increase performance/productivity, but there is a temperature range, which is more ample and also dependent on other factors such as tasks or activities or even personal factors. When answering RQ3, results showed that around 33\% of studies bring mathematical formulas to calculate productivity/performance. After analysing studies of possible methods to calculate productivity, it was noted that most studies are based on hypotheses and that researches done through experiments are relatively limited due to very few samples or due to environmental factors and insufficient number of people.

Lastly, it is important to stress the importance of the relationship between productivity and thermal comfort. It was noted that up to the present day, this connection has not been widely studied and that there are still questions that can be answered through new studies. Four basic components, that is, thermal comfort, indoor air quality (IAQ), sound and visual comfort, are identified to determine indoor environmental quality (IEQ), as well as the emotional and psychological needs of the individual. Studies show evidence that inadequate Indoor Environment Quality (IEQ) can cause illnesses, and can negatively affect the employee's well-being and productivity.

Among all the factors, thermal comfort has the greatest influence in the comfort and productivity of its occupants. Thermal comfort evaluation becomes even more relevant when the aim is to maximize performance/productivity, which occurs in industries, offices and schools. Therefore, it is necessary to ascertain how environmental variables (air temperature, average radiant temperature, air velocity and relative air humidity) and people (metabolism and clothing) influence thermal comfort and productivity. In analyzed 
studies, it was noted that some of these factors and/or a combination of these are rarely used and studied.

The search for papers was limited to the combination of keywords. Further limitations lay in bias risk assessment factors, which were not considered in the included articles in the literature review performed in this research.

Author Contributions: Conceptualization, E.E.B.; methodology, E.E.B.; formal analysis, A.M.B., E.E.B. and A.A.d.P.X.; writing - original draft preparation, A.M.B. and E.E.B.; writing—review and editing, A.M.B., E.E.B.; supervision, E.E.B.; project administration, E.E.B. and A.A.d.P.X. All authors have read and agreed to the published version of the manuscript.

Funding: This research received no external funding.

Institutional Review Board Statement: Not applicable.

Informed Consent Statement: Not applicable.

Data Availability Statement: No new data were created or analyzed in this study. Data sharing is not applicable to this article.

Conflicts of Interest: The authors declare no conflict of interest.

\section{References}

1. Gani, A.Z.; Zamberi, M.M.; Teni, M.H.M. A Review of Ergonomics towards Productivity. Int. J. Sup. Chain. Mgt. 2018, 7, 306.

2. Bellia, L.; d'Ambrosio Alfano, F.R.; Fragliasso, F.; Palella, B.I.; Riccio, G. On the interaction between lighting and thermal comfort: An integrated approach to IEQ. Energy Build. 2021, 231, 110570. [CrossRef]

3. Roelofsen, P. The impact of office environments on employee performance: The design of the workplace as a strategy for productivity enhancement. J. Facil. Manag. 2002, 1, 247-264. [CrossRef]

4. Lorsch, H.G.; Ossama, A.A. The impact of the building indoor environment on occupant productivity-part 1: Recent studies, measures, and costs. ASHRAE Trans. 1994, 100, 741-749.

5. Broadbent, D. Decision and Stress; Academic Press: New York, NY, USA, 1971.

6. Clausen, G.; Wyon, D.P. The combined effects of many different indoor environmental factors on acceptability and office work performance. HVACER Res. 2008, 14, 103-113.

7. Cui, W.; Cao, G.; Ouyang, Q.; Zhu, Y. Influence of dynamic environment with different airflows on human performance. Build. Environ. 2013, 62, 124-132. [CrossRef]

8. Hygge, S.; Knez, I. Effects of noise, heat and indoor lighting on cognitive performance and self-reported affect. J. Environ. Psychol. 2001, 21, 291-299. [CrossRef]

9. Lan, L.; Lian, X.Z.; Pan, L. The effects of air temperature on office workers' well-being, workload, and productivity-evaluated with subjective ratings. Appl. Ergon. 2010, 42, 29-36. [CrossRef]

10. Witterseh, T.; Wyon, D.P.; Clausen, G. The effects of moderate heat stress and open-plan office noise distraction on SBS symptoms and on the performance of office work. Indoor Air 2004, 14, 30-40. [CrossRef]

11. De Giuli, V.; Da Pos, O.; De Carli, M. Indoor environmental quality and pupil perception in Italian primary schools. Build. Environ. 2012, 56, 335-345. [CrossRef]

12. Al Horr, Y.; Arif, M.; Katafygiotou, M.; Mazroei, A.; Kaushik, A.; Elsarrag, E. Impact of indoor environmental quality on occupant well-being and comfort: A review of the literature. Int. J. Sustain. Built Environ. 2016, 5, 1-11. [CrossRef]

13. Roskams, M.; Haynes, B. Predictive analytics in facilities management: A pilot study for exploring environmental comfort using wireless sensors. J. Facil. Manag. 2019, 17, 356-370. [CrossRef]

14. Lamb, S.; Kwok, K.C.S. A longitudinal investigation of work environment stressors on the performance and wellbeing of office workers. Appl. Ergon. 2016, 52, 104-111. [CrossRef]

15. Fisk, W.J.; Rosenfeld, A.H. Estimates of improved productivity and health from better indoor environments. Indoor Air. 1997, 7, 158-172. [CrossRef]

16. Mui, K.W.; Tsang, T.W.; Wong, L.T. Bayesian updates for indoor thermal comfort models. J. Build. Eng. 2019, 29, 101117. [CrossRef]

17. Fanger, P.O. Thermal Comfort: Analysis and Application in Environmental Engineering; Danish Technical Press: Copenhagen, Denmark, 1970.

18. ASHRAE. Thermal Environmental Conditions for Human Occupancy; ANSI/ASHARE Standard 55-2017; American Society of Heating, Refrigerating and Air Conditioning Engineers, Inc.: Atlanta, GA, USA, 2017.

19. Kosonen, R.; Tan, F. Assessment of productivity loss in air-conditioned buildings using PMV index. Energy Build. 2004, 36, 987-993. [CrossRef]

20. Lorsch, H.G.; Abdou, O.A. The Impact of the Building Indoor Environment on Occupant Productivity. ASHRAE Trans. Symp. 1994, 100, 895-901.

21. Akimoto, T.; Tanabe, S.; Yanai, T.; Sasaki, M. Thermal comfort and productivity-Evaluation of workplace environment in a task conditioned office. Build. Environ. 2010, 45, 45-50. [CrossRef] 
22. Berglund, L.; Gonzales, R.; Gagge, A. Predicting human performance decrement from thermal discomfort and effective temperature. In Proceedings of the Fifth International Conference on Indoor Air Quality and Climate, Toronto, ON, Canada, 29 July-3 August 1990; Volume 1, pp. 215-220.

23. Clements-Croome, D. Influence of social organization and environmental factors and well-being in the office workplace. In Proceedings of the International Conference CLIMA 2000 World Congress, Naples, Italy, 15-18 September 2001.

24. Sensharma, N.P.; Woods, J.E.; Goodwin, A.K. Relationship between the indoor environment and productivity: A literature review. ASHRAE Trans. 1998, 104, 686-701.

25. Nico, M.A.; Liuzzi, S.; Stefanizzi, P. Evaluation of thermal comfort in university classrooms through objective approach and subjective preference analysis. Appl. Ergon. 2015, 48, 111-120. [CrossRef]

26. Ossama, A.A.; Gamal, M.E.K.; Amal, A.A. Correlation between indoor environmental quality and productivity in buildings. In Proceedings of the 19th of IAPS, Cairo, Egypt; 2006.

27. Parsons, K. Human Thermal Environments: The Effects of Hot, Moderate, and Cold Environments on Human Health, Comfort, and Performance, 3rd ed.; Taylor \& Francis: London, UK, 2014.

28. Bailey, R.W. Human Performance Engineering: A Guide for System Designers; Bell Telephone Laboratories, Incorporated: New York, NY, USA, 1982.

29. Wickens, C.D.; Hollands, J.G. Engineering Psychology and Human Performance, 3rd ed.; Prentice-Hall Inc.: Hoboken, NJ, USA, 2000.

30. Parsons, K.C. Human Thermal Environments: The Effects of Hot, Moderate and Cold Environments on Human Health, Comfort and Performance; The Principles and the Practice; Taylor \& Francis: London, UK, 1993.

31. Oseland, N. Environmental Factors Affecting Office Worker Performance: A Review of Evidence; CIBSE: London, UK, 1999.

32. Ilgen, D.R.; Schneider, J. Performance Measurement: A Multi-Discipline View. In International Review of Industrial and Organizational Psychology; Cooper, C.L., Roberson, S.L., Eds.; John Wiley and Sons: Chichester, UK, 1991; pp. 71-108.

33. Oseland, N.; Bartlett, P. Improving Office Productivity. In A Guide for Business and Facilities Managers; Longman: London, UK, 1999.

34. Heerwagen, J. Green Buildings, organizational success and occupant productivity. Build. Res. Inf. 2000, 28, 353-367. [CrossRef]

35. Feige, A.; Wallbaum, H.; Janser, M.; Windlinger, L. Impact of sustainable office buildings on occupant's comfort and productivity. J. Corp. Real Estate 2013, 15, 7-34. [CrossRef]

36. Candas, V.; Dufour, A. Thermal comfort: Multisensory interactions? J. Physiol. Anthropol. 2005, 24, 33-36. [CrossRef] [PubMed]

37. Seppänen, O.; Fisk, W.J. Some Quantitative Relations Between Indoor Environmental Quality and Work Performance or Health. Int. J. HVAC R Res. 2006, 12, 957-973. [CrossRef]

38. Hoque, S.; Weil, B. The Relationship between comfort perceptions and academic performance in university classroom buildings. J. Green Build. 2016, 11, 108-117. [CrossRef]

39. Zhang, F.; de Dear, R. University students' cognitive performance under temperature cycles induced by direct load control events. Indoor Air 2017, 27, 78-93. [CrossRef]

40. Bajc, T.S.; Banjac, M.J.; Todorović, M.N.; Stevanović, Ž.Ž. Experimental and Statistical Survey on Local Thermal Comfort Impact on Working Productivity loss in University Classrooms. Therm. Sci. 2019, 23, 379-392. [CrossRef]

41. Wang, D.; Xu, Y.; Liu, Y.; Wang, Y.; Jiang, J.; Wang, X.; Liu, J. Experimental investigation of the effect of indoor air temperature on students' learning performance under the summer conditions in China. Build. Environ. 2018, 140, 140-152. [CrossRef]

42. Valančius, R.; Jurelionis, A. Influence of indoor air temperature variation on office work performance. J. Environ. Eng. Landsc. Manag. 2013, 21, 19-25. [CrossRef]

43. Nematchoua, M.K.; Ricciardi, P.; Orosa, J.A.; Asadi, S.; Choudhary, R. Influence of Indoor Environmental Quality on the Selfestimated Performance of Office Workers in the Tropical Wet and Hot Climate of Cameroon. J. Build. Eng. 2019, 21, 141-148. [CrossRef]

44. Tarantini, M.; Pernigotto, G.; Gasparella, A. A co-citation analysis on thermal comfort and productivity aspects in production and office buildings. Buildings 2017, 7, 36. [CrossRef]

45. Klepeis, N.E.; Nelson, W.C.; Ott, W.R.; Robinson, J.; Tsang, A.M.; Switzer, P.; Behar, J.V.; Hern, S.; Engelmann, W. The National Human Activity Pattern Survey (NHAPS): A Resource for Assessing Exposure to Environmental Pollutants. J. Expos. Anal. Environ. Epidem. 2021, 11, 231-252. [CrossRef]

46. Wong, L.T.; Mui, K.W.; Hui, P.S. A multivariate-logistic model for acceptance of indoor environmental quality (IEQ) in offices. Build. Environ. 2008, 43, 1-6. [CrossRef]

47. Roelofsen, P. Healthy ageing: Differences between elderly and non-elderly in temperature sensation and dissatisfied. Intell. Build. Int. 2017, 9, 123-136. [CrossRef]

48. Lan, L.; Wargocki, P.; Lian, Z. Quantitative measurement of productivity loss due to thermal discomfort. Energy Build. Int. 2011, 43, 1057-1062. [CrossRef]

49. De Dear, R.J.; Brager, G.S. Developing an adaptive model of thermal comfort and preference. ASHRAE Trans. 1998, 104, 145-167.

50. Zhang, F.; de Dear, R.; Hancock, P. Effects of moderate thermal environments on cognitive performance: A multidisciplinary review. Appl. Energy 2019, 236, 760-777. [CrossRef]

51. Moher, D.; Liberati, A.; Tetzlaff, J.; Altman, D.G. Preferred reporting items for systematic reviews and meta-analyses: The PRISMA statement. Int. J. Surg. 2010, 8, 336-341. [CrossRef] 
52. Broday, E.E.; Xavier, A.A.P. A systematic literature review on thermal response votes (Tsv) and predicted mean vote (pmv). In Proceedings of the Occupational Safety and Hygiene VI-Selected contributions from the International Symposium Occupational Safety and Hygiene (SHO 2018), Guimarães, Portugal, 26-27 March 2018; pp. 13-17.

53. Marchenko, A.; Temeljotov-Salaj, A. A Systematic Literature Review of Non-Invasive Indoor Thermal Discomfort Detection. Appl. Sci. 2020, 10, 4085. [CrossRef]

54. Merabet, G.H.; Essaaidi, M.; Ben Haddou, M.; Qolomany, B.; Qadir, J.; Anan, M.; Al-Fuqaha, A.; Abid, M.R.; Benhaddou, D. Intelligent building control systems for thermal comfort and energy-efficiency: A systematic review of artificial intelligenceassisted techniques. Renew. Sustain. Energy Rev. 2021, 144, 110969. [CrossRef]

55. Mohamed, S.; Srinavin, K. Forecasting labor productivity changes in construction using the PMV index. Int. J. Ind. Ergon. 2005, 35, 345-351. [CrossRef]

56. Jin, Q.; Overend, M.; Thompson, P. Towards productivity indicators for performance-based façade design in commercial buildings. Build. Environ. 2012, 57, 271-281. [CrossRef]

57. Roelofsen, P. A computer model for the assessment of employee performance loss as a function of thermal discomfort or degree of heat stress. Intell. Build. Int. 2016, 8, 195-214. [CrossRef]

58. Rasheed, E.O.; Byrd, H. Can self-evaluation measure the effect of IEQ on productivity? A review of literature. Facilities 2017, 35, 601-621. [CrossRef]

59. Mujan, I.; Anđelković, A.; Munćan, V.; Kljajić, M.; Ružić, D. Influence of Indoor Environmental Quality on human Health and Productivity-A Review. J. Clean. Prod. 2019, 217, 646-657. [CrossRef]

60. Balzer, W.K.; Sulsky, L.M. Performance Appraisal Effectiveness. In Psychology in Organizations: Integrating Science and Practice; Murphy, K.R., Saal, F.E., Eds.; Erlbaum: Hillsdale, NJ, USA, 1990; pp. 133-156.

61. Banks, C.G.; Murphy, K.R. Toward Narrowing the Research-Practice Gap in Performance Appraisal. Pers. Psychol. 1985, 38, 335-345. [CrossRef]

62. Kaushik, A.; Arif, M.; Tumula, P.; Ebohon, O.J. Effect of thermal comfort on occupant productivity in office buildings: Response surface analysis. Build. Environ. 2020, 180, 107021. [CrossRef]

63. Ngarmpornprasert, S.; Koetsinchai, W. The effect of air-conditioning on worker productivity in office buildings: A case study in Thailand. Build. Simul. 2010, 3, 165-177. [CrossRef]

64. Chang, T.Y.; Kajackaite, A. Battle for the thermostat: Gender and the effect of temperature on cognitive performance. PLoS ONE 2019, 14, 0216362. [CrossRef]

65. Andargie, M.S.; Azar, E. An applied framework to evaluate the impact of indoor office environmental factors on occupants comfort and working conditions. Sustain. Cities Soc. 2019, 46, 101447. [CrossRef]

66. Maula, H.; Hongisto, V.; Östman, L.; Haapakangas, A.; Koskela, H.; Hyönä, J. The effect of slightly warm temperature on work performance and comfort in open-plan offices-A laboratory study. Indoor Air 2016, 26, 286-297. [CrossRef]

67. Mallawaarachchi, H.; De Silva, L.; Rameezdeen, R. Modelling the relationship between green built environment and occupants' productivity. Facilities 2017, 35, 170-187. [CrossRef]

68. Schellen, L.; van Marken Lichtenbelt, W.D.; Loomans, M.G.L.C.; Toftum, J.; De Wit, M.H. Differences between young adults and elderly in thermal comfort, productivity, and thermal physiology in response to a moderate temperature drift and a steady-state condition. Indoor Air 2010, 20, 273-283. [CrossRef]

69. Kekäläinen, P.; Niemelä, R.; Tuomainen, M.; Kemppilä, S.; Palonen, J.; Riuttala, H.; Reijula, K. Effect of reduced summer indoor temperature on symptoms, perceived work environment and productivity in office work: An intervention study. Intell. Build. Int. 2010, 2, 251-266.

70. Tanabe, S.; Nishihara, N.; Haneda, M. Indoor Temperature, Productivity, and Fatigue in Office Tasks. HVAC R Res. 2007, 13, 623-633. [CrossRef]

71. Srinavin, K.; Mohamed, S. Thermal environment and construction workers' productivity: Some evidence from Thailand. Build. Environ. 2003, 38, 339-345. [CrossRef]

72. Kang, S.; Ou, D.; Ming Mack, C. The impact of indoor environmental quality on work productivity in university open-plan research offices. Build. Environ. 2017, 124, 78-89. [CrossRef]

73. Wang, D.; Song, C.; Wang, Y.; Xu, Y.; Liu, Y.; Liu, J. Experimental investigation of the potential influence of indoor air velocity on students' learning performance in summer conditions. Energy Build. 2020, 219, 110015. [CrossRef]

74. Fahed, A.K.; Ozkaymak, M.; Ahmed, S. Impacts of heat exposure on workers' health and performance at steel plant in Turkey. Eng. Sci. Technol. Int. J. 2018, 21, 745-752. [CrossRef]

75. Liu, W.; Zhong, W.; Wargocki, P. Performance, acute health symptoms and physiological responses during exposure to high air temperature and carbon dioxide concentration. Build Environ. 2017, 114, 96-105. [CrossRef]

76. Sarbu, I.; Pacurar, C. Experimental and numerical research to assess indoor environment quality and schoolwork performance in university classrooms. Build. Environ. 2015, 93, 141-154. [CrossRef]

77. Sun, C.; Han, Y.; Luo, L.; Sun, H. Effects of air temperature on cognitive work performance of acclimatized people in severely cold region in China. Indoor Built Environ. 2020, 1-22. [CrossRef]

78. Wu, J.; Hou, Z.; Shen, J.; Lian, Z. Quantitative effect on work performance considering interactions among multiple indoor environmental factors. Build. Environ. 2020, 185, 107286. [CrossRef] 
79. Tanabe, S.; Iwahashi, Y.; Tsushima, S.; Nishihara, N. Thermal comfort and productivity in offices under mandatory electricity savings after the Great East Japan earthquake. Archit. Sci. Rev. 2013, 56, 4-13. [CrossRef]

80. Elnaklah, R.; Fosas, D.; Natarajan, S. Indoor environment quality and work performance in "green" office buildings in the Middle East. Build. Simul. 2020, 13, 1043-1062. [CrossRef]

81. Tse, W.L.; So, A.T.P. The importance of human productivity to air-conditioning control in office environments. HVAC R Res. 2007, 1, 3-21. [CrossRef]

82. Sadick, A.-M.; Kpamma, Z.E.; Agyefi-Mensah, S. Impact of indoor environmental quality on job satisfaction and self-reported productivity of university employees in a tropical African climate. Build. Environ. 2020, 181. [CrossRef]

83. Lipczynska, A.; Schiavon, S.; Graham, L.T. Thermal comfort and self-reported productivity in an office with ceiling fans in the tropics. Build. Environ. 2018, 135, 202-212. [CrossRef]

84. De Brito, F.B.R.; Da Silva, L.B.; De Souza, E.L.; Barros, T.S.R. Study of globe temperature relative to air temperature during cognitive activities in information technology laboratories. Work 2019, 1, 393-410. [CrossRef]

85. D'Oca, S.; Pisello, A.L.; De Simone, M.; Barthelmes, V.M.; Hong, T.; Corgnati, S.P. Human-building interaction at work: Findings from an interdisciplinary cross-country survey in Italy. Build. Environ. 2018, 132, 147-159. [CrossRef]

86. Hong, T.; Kim, J.; Lee, M. Integrated task performance score for the building occupants based on the $\mathrm{CO}_{2}$ concentration and indoor climate factors changes. Appl. Energy 2018, 228, 1707-1713. [CrossRef]

87. Shan, X.; Zhou, J.; Chang, V.W.C.; Yang, E.H. Comparing mixing and displacement ventilation in tutorial rooms: Students' thermal comfort, sick building syndromes, and short-term performance. Build. Environ. 2016, 102, 128-137. [CrossRef]

88. Kaczmarczyk, J.; Melikov, A.; Fanger, P.O. Human response to personalized ventilation and mixing ventilation. Indoor Air 2004, 8, 17-29. [CrossRef] [PubMed]

89. Bogdan, A.; Łuczak, A.; Chludzińska, M.; Zwolinska, M. The effect of personalized ventilation on work productivity. Int. J. Vent. 2012, 11, 91-102. [CrossRef]

90. Tsutsumi, H.; Tanabe, S.; Harigaya, J.; Iguchi, Y.; Nakamura, G. Effect of humidity on human comfort and productivity after step changes from warm and humid environment. Build. Environ. 2007, 42, 4034-4042. [CrossRef]

91. Bogdan, A.; Chludzińska, M.; Koelblen, B.; Ogłodzinski, K.; Młynarczyk, M. Sensitivity of personalized ventilation air terminal device geometry with regard to a human thermal sensation. Sci. Technol. Built Environ. 2017, 23, 1105-1112. [CrossRef]

92. Vilcekova, S.; Meciarova, L.; Burdova, E.K.; Katunska, J.; Kosicanova, D.; Doroudiani, S. Indoor environmental quality of classrooms and occupants' comfort in a special education school in Slovak Republic. Build. Environ. 2017, 120, 29-40. [CrossRef]

93. Geng, Y.; Ji, W.; Lin, B.; Zhu, Y. The impact of thermal environment on occupant IEQ perception and productivity. Build. Environ. 2017, 121, 158-167. [CrossRef]

94. Asere, L.; Mols, T.; Blumberga, A. Assessment of indoor air quality in renovated buildings of Liepaja municipality. Energy Procedia 2016, 91, 907-915. [CrossRef]

95. Tanabe, S.; Kobayashi, K.; Kiyota, O.; Nishihara, N.; Haneda, M. The effect of indoor thermal environment on productivity by a year-long survey of a call centre. Intell. Build. Int. 2009, 1, 184-194. [CrossRef]

96. Suzianti, A.; Suradi, J.; Nurtjahyo, B.; Brakumara, Y. Analysis of teh indoor environment quality's impacts on human performance. Int. J. Mech. Eng. Robot. Res. 2017, 6. [CrossRef]

97. Barbic, F.; Minonzio, M.; Cairo, B.; Shiffer, D.; Dipasquale, A.; Cerina, L.; Vatteroni, A.; Urechie, V.; Verzeletti, P.; Badilini, F. Effects of different classroom temperatures on cardiac autonomic control and cognitive performances in undergraduate students. Physiol. Meas. 2019, 40, 054005. [CrossRef]

98. Zhao, J.; Zhu, N.; Lu, S. Productivity model in hot and humid environment based on heat tolerance time analysis. Build. Environ. 2009, 44, 2202-2207. [CrossRef]

99. Wong, L.T.; Mui, K.W. Efficiency assessment of indoor environmental policy for airconditioned offices in Hong Kong. Appl. Energy 2009, 86, 1933-1938. [CrossRef]

100. Jiang, J.; Wang, D.; Liu, Y.; Xu, Y.; Liu, J. A study on pupils' learning performance and thermal comfort of primary schools in China. Build. Environ. 2018, 134, 102-113. [CrossRef]

101. Koteswara Rao, K.; Lakshmi Kumar, T.V.; Kulkarni, A.; Hoi Ho, C.; Mahendranath, B.; Desamsetti, S.; Patwardhan, S.; Dandi, A.R.; Barbosa, H. Sudhir Sabade Projections of heat stress and associated work performance over India in response to global warming. Sci. Rep. 2020, 10. [CrossRef]

102. Koehn, E.; Brown, G. Climatic effects on construction. J. Constr. Eng. Manag. 1985, 111, 129-137. [CrossRef]

103. Thomas, H.R.; Yakoumis, I. Factor model of construction productivity. J. Constr. Eng. Manag. ASCE 1987, 113, 623-639. [CrossRef]

104. Jensen, K.L.; Toftum, J.; Friis-Hansen, P. A bayesian network approach to the evaluation of building design and its consequences for employee performance and operational costs. Build. Environ. 2009, 44, 456-462. [CrossRef]

105. Wyon, D.P. Indoor environmental effects on productivity. In AQ 96 Paths to Better Building Environments; Kevin, Y., Ed.; ASHRAE: Atlanta, GA, USA, 1996.

106. Onyeizu, E. Can Architecture Increase Productivity? A Case of Green Buildings. Ph.D. Thesis, The University of Auckland, Auckland, New Zealand, 2014.

107. Byrd, H.; Rasheed, E.O. The Productivity Paradox in Green Buildings. Sustainability 2016, 8, 347. [CrossRef]

108. Leaman, A.; Bordass, B. Productivity in buildings: The 'killer' variables. Build. Res. Inf. 1999, 27, 4-19. [CrossRef]

109. Haynes, B. An evaluation of office productivity measurement. J. Corp. Real Estate 2007, 9, 144-154. [CrossRef] 
110. Haynes, B.P. The impact of office layout on productivity. J. Facil. Manag. 2008, 6, 189-201. [CrossRef]

111. LaBar, G. Why employees are sick of indoor air. Occup. Hazards 1992, 54, 32-36.

112. Frontczak, M.; Wargocki, P. Literature survey on how different factors influence human comfort in indoor environments. Build. Environ. 2011, 46, 922-937. [CrossRef]

113. Alajmi, A.F.; Baddar, F.A.; Bourisli, R.I. Thermal comfort assessment of an office building served by under-floor air distribution under-floor air distribution (UFAD) system-A case study. Build. Environ. 2015, 85, 153-159. [CrossRef]

114. Andargie, M.S.; Touchie, M.; O'Brien, W. A review of factors affecting occupant comfort in multi-unit residential buildings. Build. Environ. 2019, 160, 106182. [CrossRef]

115. Haynes, B.; Suckley, L.; Nunnington, N. Workplace productivity and office type: An evaluation of office occupier differences based on age and gender. J. Corp. Real Estate 2017, 19, 111-138. [CrossRef]

116. Byrne, N.M.; Hills, A.P.; Hunter, G.R.; Weinsier, R.L.; Schutz, Y. Metabolic equivalent: One size does not fit all. J. Appl. Physiol. 2005, 99, 1112-1119. [CrossRef]

117. Knapton, S. Women Shiver at Work in 'Sexist' Air Conditioning. The Telegraph. 2015. Available online: https://www.telegraph. co.uk/science/women-shiver-at-work-in-sexist-air-conditioning/ (accessed on 26 May 2021).

118. Pager, T. Can an Office Temperature Be 'Sexist'? Women, and Science, Say So. The New York Times. Available online: https:/ / www.nytimes.com/nyregion/office-temperature-sexist-nixoncuomo.htm (accessed on 26 May 2021).

119. Clements-Croome, D.E. (Ed.) Indoor environment and productivity. In Creating the Productive, Work, 2nd ed.; Taylor \& Francis: London, UK, 2006; pp. 25-54.

120. Wang, H.; Hu, S. Experimental study on thermal sensation of people in moderate activities. Build. Environ. 2016, 100, 127-134. [CrossRef]

121. Yau, Y.H.; Chew, B.T. Adaptive thermal comfort model for air-conditioned hospitals in Malaysia. Build. Serv. Eng. Res. Technol. 2014, 35, 117-138. [CrossRef]

122. Broday, E.E.; de Paula Xavier, A.A. A Method for Predicting the Actual Percentage of Dissatisfied (APD) through a Simple Proposition of Thermal Comfort Zones in a Working Environment. Work 2020, 67, 599-609. [CrossRef] 